\title{
Leadership Styles and Value Systems of School Principals
}

\author{
Abu-Hussain. Jamal* \\ Department of Education, Al-Qasemi Academic College of Education, Baqa El-Gharbieh, Israel \\ *Corresponding author: jamal_ah@qsm.ac.il
}

Received November 19, 2014; Revised December 01, 2014; Accepted December 25, 2014

\begin{abstract}
The reforms conducted in the field of education are directed towards the changing manner of school management. The change is expressed in the transition from external supervision of schoolwork to the empowerment of school's staff, with a change of the principal's and teacher's roles. It requires accountability from school's principles and staff inproviding results of teaching and effective functioning of the school. The goal of this paper is to review research literature in order to determine the most effective leadership model in the new conditions of school management. In order to attain this goal, a consistent review of literature was performed on the following subjects: leadership evolution; transformational and transactional leadership styles; the links between a leadership style and organizational variables; the relationship between value systems and leadership styles of school's principles. Approaches, methods, models, and means are analyzed during the examination of leadership evolution. Many studies reveal that leadership behavior is an important predictor of its effectiveness. A comparative examination of transformational and transactional leadership styles gives evidence for preference of transformational style relative to its influence on organizational variables. The literary review indicates that transformational leadership essentially improves the functioning of school and teaching processes. The effect of a value system on leadership styles of school principals is examined. As a result, it is determined that principals with a moral value system lean more towards a transformational leadership style and principals with a pragmatic value system lean more towards a transactional leadership style. Thereby, the review shows that effective leadership can be provided as a result of searching for correlations between the value systems and leadership styles.
\end{abstract}

Keywords: leadership styles, value system, school principals

Cite This Article: Abu-Hussain. Jamal, "Leadership Styles and Value Systems of School Principals." American Journal of Educational Research, vol. 2, no. 12 (2014): 1267-1276. doi: 10.12691/education-2-12-22.

\section{Introduction}

In the 1980's, experiments around the world were started in order to implement reforms in the field of education. These reforms focused on the change in the organizational structure of schools and the manner in which they were managed. The change was expressed in the passage from external supervision of schoolwork to the empowerment of school's staff, with a change in the definition of the principal's and teacher's roles, and more responsibility taken by the school's staff for its functions and results. This was accompanied by a demand for accountability for an examination of school's functioning and quality and an increase in the efficiency of its functioning.

The change grants authority to a school principal. According to the new leadership role, on the one hand, he should promote an organizational culture characterized by standards and transparency and, on the other hand, he should solve a huge quantity of various daily problems [2,51,83]. As a result, a question arises concerning the ability of the school principals to lead school in the complex modern reality.
The need to evaluate a school principal as an educational leader who should lead the educational system successfully in coping with the many challenges it faces engenders questions. Are there differences in value systems of school principals? What is the appropriate leadership style that would result in more efficient functioning of schools in the present reality? Is there a theoretical and research correlation between a values system of a school principal and his (her) leadership style? [1].

The goal of this paper is to review research literature in order to determine the most productive value system and leadership style, an influence of the principal's value system on his (her) leadership style, and correlation between moral and pragmatic value systems, between transformational and transactional leadership styles.

\section{Leadership Styles and Value Systems of School Principals}

\subsection{Leadership Evolution}

Professional literature on leadership is rich in hypotheses and definitions. Most hypotheses and studies 
on leadership have engaged in the leader's personal background, character traits, perceptions, typical behaviors and actions.

From the 1950's, studies on leadership have focused mainly on the individual's personality and character traits [118]. According to the "Great Man Theory", which formed a basis for the trait approach, a leader is someone endowed with extraordinary traits with which he influences the team. At first, research attempted to identify unique traits characterizing a leader, with no reference to the interactions between him and the rest of the team and the society to which he belongs However, after it became clear that the findings were contradictory and the explanations of the trait approach were not sufficient [126]. Consequently, research turned to an examination of the specific behaviors of leaders. The behavioral approach focused on the examination of a leader's behaviors, because they were always explained against the background of a given situation. This research approach was better known as the situational approach [97].

Leadership research from 1950 to 1960 focused on development of the situational approach with an emphasis on the most efficient leadership style [119]. Within the framework of the situational approach, models describing different leadership styles and their influence on various situations are produced. For many years, research focused on the development and examination of models describing different leadership styles and their influence on various situations. Thus, a specific leadership style would be effective under certain conditions and lose its effectiveness when the conditions change. Thompson deducted from this that when attempting to increase the effectiveness of any particular leader, he shouldn't learn to adapt his style to the situation, but rather construct the situation that corresponds to his style [121].

From the end of the 1970's to the mid-1980's, the emphasis moved over to the correlations between leaders and followers (Bolden et al., 2003), with an analysis of situational variables [42,61]. According to Fielder (1972), the appointment of leaders should be undertaken in accordance with the type of mission granted them, and the development of leaders by creating the most convenient conditions for them, in contrast to House's path-goal theory [61], which claims that a leader's behavior is directed to the manner in which organizational goals are set and attained. The role of a leader is as mediator between organizational goals and individual needs, and therefore, his behavior (style) should correspond to the situational variables, so that the required organizational output will be attained [121].

At the end of the 1980's, approaches on leadership concentrated on the integration of variables to explain the effectiveness of leaders with reference to their followers in addition to their effect on the structure, culture and performance measures of the organization itself [11]. Approaches are combined to create a new genre of hypothesis that stresses symbolic behavior, vision and morals [121]. Like, servant leadership which awakens from the desire to serve more than to lead, and stresses the obligation of the leader to serve his followers. Transformational and transactional leadership decentralized leadership according to which the leader promotes additional leaders [5,17].
A review of knowledge on leadership accumulated to the beginning of the 1990's reveals an extensive range of models and hypotheses that have attempted to explain leadership, including its styles, the detection and development of leaders and more.

In the 1990's, researchers developed and perfected the idea that leadership can be ranked according to the degree of effectiveness and activeness of its effect. Bass \& Avolio [8] presented the full range model, according to which a leader expresses different styles of leadership in his behavior in sequence, beginning with non-leadership, through to transactional leadership and up to transformational leadership. According to the model, it is inherent in the abilities of leaders to sweep their subordinates into demonstrating efforts and performance that exceed their personal feasibility, with the transformational leadership style.

In the $21^{\text {st }}$ century, the character traits and behaviors of leaders continued to be studied. Many studies revealed that leader behaviors are important predictors of leadership effectiveness [66]. For example: Collins' Leadership model Step 5 [26]; models of servant leadership; autonomous leadership [28]; educational pedagogic leadership [50].

\subsection{Leadership Styles}

The question of a leader's effectiveness has become a central issue in organizational research. Recent studies have attempted to develop an integrative leadership model combining leader characteristics (gender, intelligence, personality, etc.) and his behaviors (transformativerewarding, consideration, etc.). The integrative model may serve as a predictor of leadership efficiency, which would assist organizations in improving their choice of leader and developing effective work methods. Therefore, identification and study of a leader's prevalent personal style is an important, central element in the development of leadership. In addition, it is important to distinguish between leadership style and behavior, where style refers to something that characterizes a specific person throughout different situations, and this is what many researchers in the $21^{\text {st }}$ century espouse and try to prove.

Organizational leadership is usually expressed in the effect on people's motivation to perform tasks over time, while maximizing the means of motivation and with minimal use of coercive measures [69]. Leadership style is the manner in which the leader undertakes the process of convincing and recruiting people for specific objectives and retaining them throughout all of the tasks until the objectives are attained [12].

There are many ways to describe leadership styles, and the variety increases with every book or paper published on leadership. Lewin, Lippit, \& White's study [78] served researchers as a basis on which to lean and continue in their own research. This study examined the effect of three leadership styles: autocratic, democratic, or laissez-faire.

The study revealed that an autocratic style was an advantage in attaining a high level of performance shortterm, but was accompanied by negative feelings. The democratic style was advantageous in team members' feelings, although their performance levels were lower [77]. This discussion continued from study to study, accompanied by additional hypotheses - from one- 
dimensional, in Lewin, Lippit \& White's study [78], to two-dimensional in the Ohio contingent's study, which proposed the possibility of combining two styles.

Hersey \& Blanchard [55] added a conditional variable to these dimensions - maturity - in their Cycle of Life model, where any style will be effective in reference to the team's level of maturity. This model does not recommend the most effective style, but rather deems the effectiveness of the leadership style conditional upon both the team's level of maturity and development and a definition of the situational variables affecting the leadership style.

Reddin's model is also constructed on situationdependent hypotheses, and he does not attempt to identify the most effective leadership style but rather the effectiveness and ineffectiveness of each and every style [101]. This model is considered to be a most sophisticated, complex mapping of leadership styles, producing an image of a leader directed towards human relations - a man for all seasons - which suggests transformational leadership [25].

Classification is dependent upon two typical behaviors or styles of leaders: a leadership style that emphasizes the duties of the team, and a style that emphasizes consideration of the team members and concern for their needs [91]. This division has guided many researchers up to now, with suggestions for other classifications of leadership styles, such as leadership that generates feelings, from an emotional perspective of the leaderfollower bond [98].

A leadership style is determined by the leader's approach in the active process. Since the leader's main role is to bring about the execution of tasks by other people, he must focus on his followers' productivity while maintaining good relations with them [49]. According to a managerial grid approach of Blake \& Mouton (1964), the ideal leader is the one with the highest score from both a task-oriented aspect and a human relations aspect.

Researchers Clark \& Pratt [24] have identified four managerial styles that match everyone to different organizational stages. This approach links the manager's managerial style to an organizational situation and status in his life cycle [77]. A similar but more complex situational approach that stresses the importance of matching a managerial style to the organization's place in the life cycle has been developed by Adizes [3]. Two conclusions can be drawn from Adizes's descriptions: first - the establishment of one, dominant leadership style will claim its price in the loss or reduction of existing energies when other styles exist; second - there is a need for one leading style in the different stages of an organization's life [98].

The measure of practical efficiency of any leadership style can be assessed by its implications on the followers, such as: making extra efforts, efficiency and satisfaction, feelings of frustration and optimism [8]. Together with its effect on different dimensions within the organization, such as the control dimension, it suggests that in order to be efficient in making decisions on required actions, leaders must develop an awareness and sensitivity to changing situations and organizational constraints.

Leadership styles in the educational organization are no different from leadership styles in other organizations. In addition, they include aspects of task-orientation and orientation towards people. As a school principal is the leader of a team, his leadership style has great impact. The school principal's leadership style is one of the crucial factors in team success, due to its effect on satisfaction, commitment, motivation, quality and level of teacher performance, as well as its indirect effect on student achievements [44].

Leadership style affects the ability of the school to cope with changes occurring around it and on its level of effectiveness [111], teacher satisfaction both directly and indirectly through their perceptions of their role [15], the nature of thought and types of coping and teachers' feelings regarding the extent of autonomy they feel in their work. A study among 160 teachers in Israeli schools [6] revealed that the principal's support of the teacher and participation in decision-making and in determining school policy contributed to a sense of more freedom and initiative in their work.

In light of the above review, it was found that a leadership style expressing attention to employee needs, appreciation, warm human relations, empathy, learning, freedom of action, empowerment, delegation of authority, participation and involvement in decision-making, power and influence, open relations, teamwork, open communication and information, interesting and challenging work, interest in and satisfaction from work promotes employee satisfaction, commitment and motivation. At the same time, a task-oriented leadership style stressing the importance of achievement and excellent performance, welfare, yield, maintaining objectives, rewards for achievements, performance evaluation, efficiency, quality and quantity of performance are essential for the success of the team and the organization [77]. Leadership style is considered to be a component contributing significantly to the organization's success, particularly when human assets and resources are considered to be the main factor in the organization's success and prosperity [13].

\subsection{Transformational and Transactional Leadership Styles}

Both the needs of the organization and of the individual affect a leadership style. With some managers, the tendency to supply organizational needs increases, and with others, their first priority is concern for their followers' needs. Current professional literature on leadership engages in two levels of influence existing between a leader and his followers. One influence stems from the understanding that the leader creates the concept of cost/benefit. This influence appears in literature under the title of "transactional leadership". The second influence of leaders is termed "generating feelings", which increases leaders' awareness to what is important and appropriate for employees and provides significance to what they do. This type of leadership appears in professional literature under the title of "transformational leadership", which focuses on the process by which leaders can affect performance and achievement [9,98].

Bass[11] defined transactional leadership in broader terms than Burns[18], such as "reward-dependent behavior", including clarification on the work required obtaining a reward and the use of dependent rewards and incentives to affect motivation. Another element called "active management-by-exception" includes a follow-up 
on followers and corrective actions to ensure that the work is being performed effectively. A third element, known as "passive management-by-exception" was added by Bass \& Avolio [10] and includes usage of dependent punishments and other corrective actions, in a response to clear exceptions from accepted standards and performance.

Burns [18] described transformational leadership as a process in which "leaders and followers make each other advance to a higher level of morality and motivation". These leaders try to raise the awareness of their followers by turning to higher ideals and moral values like freedom, justice, equality, peace, humanitarianism, and not to lower feelings like fear, greed, envy or hatred. In terms of Maslow's Hierarchy of Needs, transformational leaders activate higher needs in their followers. Followers are raised from their "daily selves" to their "better selves", in contrast to transactional leaders with an orientation of exchange, who reward their supporters on attaining the objectives set in advance.

Bass [11] added to Burns' more preliminary ideas. A leader shapes and motivates his followers by increasing their awareness of the importance of task results, by convincing followers to rise above their own personal interests for the sake of the organization or team and activating their higher needs.

Transformational leaders can attain these conditions through one or more of the following manners: they tend to be charismatic to their followers, thus inspiring them; they inspire an intellectual awakening and consideration of the individual, where intellectual awakening is a process in which leaders increase the awareness of their followers to problems and influence their followers to see problems from a new perspective; inspiration is defined as the extent to which a leader passes on a vision in a captivating manner, using symbols to focus followers' efforts and illustrate inferior leadership [9].

Transformational leadership is expressed in the behaviors of the followers that bring leaders to a higher level of awareness of the importance of their mission and increase their level of motivation, maturity and aspirations, as well as their reference to the need for achievement, self-realization, social welfare, the success of the organization and concern for its social environment [9]. Transformational leadership creates a change in expectations and aspirations of the followers themselves. Despite this, transactional leadership is expressed in behaviors like: focus on followers' immediate needs, setting clear objectives and granting rewards for performance, placing sanctions on inappropriate behavior [98].

Transformational leadership creates a significant change in the lives of people and organizations. It reshapes concepts and values, changes employee aspirations and expectations and changes organizational culture. It is not based on concrete exchange relationships, but rather on the leader's personality and character traits and on his ability to generate change through inspiration of a vision and significant objectives [77]. Based on Hebert's research findings [54], one can conclude that leaders can better develop efficient leadership talents by being more aware of their strong and weak points in emotional intelligence, together with an improvement in their behavior as transformational leaders [54].
Bass [9] and Sergiovanni [111] consider transactional leadership to be an important, central element in the preservation of organizations, in filling an agenda and putting things into action. It does not necessarily cause improvement, in contrast to transformational leadership which grants an incentive to try to improve one's performance. A transformational leader translates each daily action, each activity into the meanings one can gain from them in realizing the future picture: "proactive thinking", in contrast to a transactional leader, who does not link his daily activities to the objective for which all the effort is invested; he simply manages the day-to-day as a routine that must be maintained, and handles problems with the perception of a disruption in routine.

Let's take, for example, typical situations of success and failure: In situations of success, the transactional leader will award money, a letter of appreciation, etc.; the transformational leader will also grant a reward (and it may be identical to the transactional leader's award); however, the transformational leader will take advantage of this opportunity of granting an award for success to raise the bar towards future performance. He'll say to his followers: "You have succeeded; you have shown that you are capable of doing well, and the next time we'll make it worth more, better...". Thus, the success has become part of the transformational effect. In the case of failure, a transformational leader will also use punishments; however, because he is proactive and transformational, he will also make relevant use of this punishment for the future; for example, he will never give a punishment that might hinder his followers' belief in their self-efficacies, and he will take advantage of the failure to teach a lesson, thus promoting working towards maintaining the future picture, which is, as mentioned, the compass that guides his daily activities [98]

According to many researchers, transformational leadership engages in the creating of a shared interest that unites leaders and followers [9]. This is the mission of the transformational leader. In contrast to the transactional leader who uses conditional reinforcement with his subordinates, the transformational leader inspires, intellectually stimulates and considers each subordinate. Transformational leadership requires high moral/ethical development [9].

\subsection{The Links between Leadership Style and Organizational Variables}

Many studies have engaged in the links between leadership style and organizational variables which have implications on employee performance and efficiency. Today, the starting point of most studies is that transformational leadership of an organization has a more positive effect on the level of organizational performance than transactional leadership. In a study measuring the direction of influence [70], it was found that an employee's satisfaction influences an organization's performance and output, and not the opposite.

An analysis was recently conducted to review the last 25 years of discussion on transformational leadership and performance. The meta-analytic study revealed a positive correlation between transformational leadership and followers' performance on an individual level in reference to various criteria. In addition, a positive correlation was 
found between transformational leadership and team and organization performance [122]. Transformational leadership has been found to be more closely linked to leader efficiency and employee satisfaction than transactional leadership [35].

Other research has studied the influence of a transformational leadership styleon the effectiveness and innovation of organizations and has found that a transformational leadership style has a more positive influence on organizational performance than does transactional leadership (Lowe et al., 1996). A similar finding was discovered in another study, where a project manager with a transformational leadership style was found to positively influence the project's actual performance and to awaken emotional intelligence, which contributes to actual performance. There is a single positive correlation between transformational leadership and the concept of leaders as having integrity. The presence of integrity may improve organizational efficiency.

Transformational leaders have the potential to influence their employees' perceptions by involving them in the construction of an organizational culture and encouraging communication among employees [13]. Transformational leadership is found to be positively and significantly correlated with a constructive culture of an organization and adds a considerable percentage of variance in explaining the parameter of a constructive culture. In contrast, transactional leadership is found to be positively and significantly correlated with a defensive culture of an organization and adds considerable variance in the prediction of a defensive culture [38].

Ling et al. [80] found that a leader with a transformational leadership style fills an important role in the promotion of initiatives and shapes the characters of his senior management from the aspect of behavioral integration (quality and integrity of decision-making), decentralization of responsibility, the tendency to take risks, long-term compensation. There have been many recent empirical studies examining the implications of transformational leadership on different organizational variables like individual perceptions of transformational leadership, etc.

The team-level climate of transformational leadership is positively correlated with an individual's adaptation to his position [21]. Desire of employees for empowerment is positively correlated with an improvement in implementation of transformational leadership [47]. In the link between transactional and transformational leadership styles and individual results (i.e. the concepts of justice and trust in leaders), it was found that transformational leadership is significantly correlated with procedural justice and trust in leaders despite the partial correlation with transactional leadership. Statistically, this result confirms that transformational leadership is an important predictor of procedural justice and trust in leaders [65]. Family businessmen with transformative leadership styles positively influence commitment among their employees, including their commitment to stay [45].

Whether the organization is business or commercial, military or private (like a school), the organizational leader provides a significant contribution to its success, as reflected in the success of its employees and their motivation to attain organizational vision and attain its objectives, particularly under today's conditions of reality, where the speed and intensity of change cannot even be predicted. In this environment, a leader's style is crucial and may assist him in coping with changes.

\subsection{School Leadership}

The characteristics mentioned above for transactional and transformational leadership regarding organizations are also dominant in schools. School principals are considered to be the central educating figure constituting the leadership meant to lead the educational system into the $21^{\text {st }}$ century, so it can cope with the challenges it faces, working within a system that has undergone many changes. These principals may be characterized as leaders with a transformational or transactional leadership style, and this style can affect the principal's behavior within the school in relation to assessment as well.

Transformational leadership has shown to be appropriate to a complex and dynamic work environment with many intellectual challenges facing the educational manager and team [71]. Researchers claim that transformational leadership succeeds in coping with educational challenges in a changing environment and contributes to the school's success in implementing innovations. The influence of these leaders is expressed in the school's culture and vision as well as in planning, structure and organization [22,72].

Popper [98] define transactional leadership of school principles vs. transformational leadership and state that "Transactional leadership is leadership in which relationships with teachers are based upon an exchange for some valued resource. To the teacher, interaction between administrators and teachers is usually episodic, short-lived and limited to the exchange transaction. Transformational leadership is more potent and complex and occurs when one or more teachers engage with others in such a way that administrators and teachers raise one another to higher levels of commitment and dedication, motivation and morality. Through the transforming process, the motives of the leader and follower merge."

Many studies reveal empirical evidence supporting transformational leadership, as in Leithwood's study [71], which reported on seven quantitative studies and came to the conclusion that transformational leadership, considered to be a complex model, had a direct and indirect effect on the progress of initiatives in renewed school structures and on teacher expectations of student achievements.

Transformational leadership provides school leadership with a normative approach that makes progress particularly in the process by which leaders can influence school achievements, and not only regarding results. Bass [9]claims that transformational leadership serves today as a convincing model for educational leaders. Davies [33] found that leaders are more effective when they are actively transforming, presenting and marking different cultural factors in school life; this is part of the creation of the meaning and experience of the school story.

A clear conclusion from the findings and descriptions of many of the studies mentioned above is that transformational leadership may be more effective than transactional leadership in both organizations and educational institutions, when considering the leadership 
required in the $21^{\text {st }}$ century. With its turbulent environment characterized today by constant change, leaders find themselves filling central positions, and both large and small organizations are seeking a special leader who is not only considered to be a strategic leader but also a transformative leader, who, in this fast world, can assist in making organizations competitive [23].

Su-Tan study [120] reveals that transformative leadership has been found to be the most appropriate leadership style for leading academic institutions. Educational leaders need not lead their organization based on give-and-take relationships, but rather on the leader's personality, character traits, ability to bring about change by being a leader's role model, as well as always committing to a shared vision and objectives. One of the conclusions in his article is that the heads of educational institutions must have more transformational and less transactional leadership style to be able to remain efficient in filling their leadership obligations [120].

Therefore, it is reasonable to assume that a school will require its principal to act as a transformational educational leader in order to cope with the challenges of the dynamic, changing environment in which the school functions. In view of this dynamic, changing reality, the rising competition and technological changes that increase the need among organizations for leadership that can unite and rally forces to attain organizational objectives without need for use of any types of rewards, by awakening autonomic motivation, loyalty and commitment.

More than a few studies have confirmed the positive influence of transformational leadership on school parameters. A study undertaken by Eyal \& Roth [39] revealed that transformational leadership positively influences teachers' motivation and welfare, awakening their autonomous motivation. In addition, it is negatively linked with burnout, despite transactional leadership awakening controlled motivation among teachers and being positively linked with burnout [39].

A conclusion that can be drawn from the above is that organizational leaders in general and school principals in particular have the power to considerably influence processes and results, and, through them, to affect the overall behavior and performance of their followers. Leadership is a dynamic process of motivating people to perform tasks over time. The studies reviewed above have proven that transformational leadership has positive implications on these behaviors and performances in comparison to transactional leadership, and therefore, leadership is perceived to be one of the central roles of a school principal. The term "leadership" expresses the vision, the mission, the values and inspiration; the term "management" refers to the implementation of the resources. The educational leader is actively involved in the development of the educational system and the supervision of its undertakings. In research literature, one can distinguish between a manager's role as one who is concerned with maintaining the functioning of the school as an organization and the characteristics of a manager as a leader who is capable of ensuring the effective functioning and excellence of the organization. Effective functioning is expressed in the design of the teaching such that student achievements will improve and there will be satisfaction among the teaching staff and student population.
As seen in the above review, a school principal is a central educational figure in schools and his leadership style may affect educational practice. Within this framework, he is required to lead the school and teachers to attain objectives and work to promote efficient teaching processes in the school, where the principal's leadership style is considered today to be one of the most important and influential variables in his functioning at school.

\subsection{The Relationship between Value Systems and Leadership Styles of School Principals}

An individual's value system is defined as an enduring organization of beliefs and rules that assist an individual in selecting alternatives, resolving conflicts and making decisions [103]. Rokeach states that a value is a conceptual matter that transcends specific situations; someone who advocates a certain value means he fully believes that a certain mode of conduct is preferable, both personally and socially, over other modes of conduct. Consistent with Rokeach's definition is claim of Sikula [113] that an individual's value system is the element that determines his hierarchy of preferences, his perception of the world, his behavior and the manner in which he selects his information.

People differ from each other in the importance they attribute to different values. This different attribution is a person's hierarchy of values, reflecting his personality and guiding his perceptions, evaluations and choices of behavior [108]. Studies have found that in different cultures there is group agreement regarding priority of different values; however, there are interpersonal differences regarding priority of values [67,109].

A value system can be sorted by orientation: a pragmatic value system - such as achievement, obedience, ambition, aggression, competition, etc., and a moral value system - tolerance, contact with others and relationships, equality, friendliness, family and personal security, etc. $[46,103]$. The distinction between being pragmatically value-oriented and morally value-oriented is found to be valid in research among business managers [37] among school principals [46].

Research studying the links between values and behavior has found that values influence behaviors in situations where one is aware of one's values (Sagiv \& Schwartz, 1995). Studies have shown that values influence both hypothetical behavior (Feather, 1995) and the choice of realistic behaviors [108].

The value system and leadership style of organizational managers have been linked in various studies. Professional literature reveals a correlation between a person's value system and behaviors. Literary reviews indicate potential links between a manager's value system and behavior in different areas of management. A clear correlation between managers' value systems and their behavior, functioning and the manner in which they make decisions was revealed in a study conducted among organizational managers in Jordan [52]. It is reasonable to assume that this is also the case for school principal's leadership styles.

It is reasonable to assume that a school principal's value system affects his leadership style. Thus, as he is responsible for leading his teachers in a wise and productive manner, he should have specific skills like the ability to work in full cooperation with his staff, to assist 
teachers in learning to accurately evaluate and use results in a productive manner, to use information to improve the study program and teachers' instruction, to communicate effectively with all members of the school community [117].

These necessary capabilities overlap the characteristics of a leader with a transformative leadership style as defined in professional literature. The characteristics are leaders and followers raising each other to a higher level of motivation and morale; great sensitivity to the needs of his community; creativity, imagination and daring; the ability to shape people's expectations and produce new ones they didn't have at the beginning of their interaction with him; teaching them to meditate, contemplate and cope with abstract contents; handling his followers' feelings and personal needs in an individual, nurturing manner, and to serveas a wise and loyal advisor. His followers will say, "he made me reassess the problem"; he will present new and challenging ways to conceive of reality, like turning a crisis into an opportunity, failure into learning, successes into milestones; he will have the ability to translate new ideas into concrete actions and behaviors that tangibly express intentions and the way to carry them out.

Studies and experimentation have shown that the role of a school principal today is more complex, responsible, and demanded than in the past. The areas of responsibility imposed upon principals have intensified over time and their workload has increased. Behind the great energies and activities that characterize the work of a school principal lie the values from which their vision is constructed and from which their passion for their work originates. These values nurture them and enable them to continue their tasks, serve as compasses for advancement and grant meaning to their daily activities [115].

A study conducted in Canada among approximately 100 elementary school principals revealed that values fill an important role in the decision-making process among school principals and affect their daily behavior [4].In four schools in different districts in Canada [88], it was found that the values of school principals affect their behaviors and the manner in which they make decisions. The four principals preferred moral values, and their behaviors were characterized more as transformational behaviors.

A study conducted by Day, Harris \& Hadfield[34] among 12 schools in England and Wales illustrates the values adopted by many school principals. The study focused on principals defined as being effective both according to criteria of the Office of Standards in Education (Ofsted) and their reputation among their colleagues. Researchers interviewed teachers, parents, students and members of the school management committee, as well as the principals themselves. They state that good leaders act according to clear personal and educational perceptions and pass them on. These perceptions reflect their moral intentions regarding the school.

The link between a value system and leadership style in the educational system has been studied in two researches in Israel. One was conducted by Gaziel [46]. In a random sampling of 80 first-degree students in education management at Ben Gurion, Bar-Ilan and Tel Aviv Universities, participants filled out a leadership style questionnaire developed by the researcher. The students responded to Rokeach's value questionnaire [103]to study the orientation of their values. Gaziel detected a correlation between students' value systems and their preferred leadership style. Those with a pragmatic value orientation tended to prefer transactional management behaviors. In contrast, those with a moral value orientation preferred transformative management styles.

The second study was conducted among school principals in the Arab education system in Israel [1,2]. The study stated that principals with pragmatic value systems were perceived by their teaching staff to grant rewards for improvements in performance and apply sanctions for inappropriate behavior, focusing on short term tasks and seeking shortcuts to attain objectives. In other words, their leadership style was characterized by transactional behaviors. Principals with moral value systems were perceived to be principals who served personal example, obtaining the best from each teacher, relating to all subordinates as fundamentally good people, nurturing the teachers, and encouraging them to be creative and to introduce changes in the system. The study also revealed a large spread in teachers' responses, which indicates the differences in teachers' perceptions of their principal's leadership style. A school principal's value system may influence the school's objectives, the processes occurring within it, its systems and directions of action. The above studies clarify how important it is to know and understand the factors that influence a school principal's leadership style.

Professional literature indicates clear signs that a school principal's value system enables him to have a transformative leadership style that will contribute to the improvement of school functioning, and in particular, to more efficient teaching processes and more significant study among students. It is reasonable to assume that those with moral value systems who tend towards a transformative leadership style, will succeed in challenging their staffs, will lead organizational processes that will result in empowerment of teachers and an improvement in their performance, and will show interest in the process and not just in the final result, performing evaluation processes and accompanying the teachers.

Transformative leadership of a school principal is expressed in the motivation of his staff to take an active part in determining criteria for success and evaluation. These criteria will serve in performance evaluation, in discussions on study programs and on teaching strategies and further interactions with teachers as individuals and teams [48]. Thus, transformative leadership enables an empowerment process for teachers. It brings good organizational results, improves teachers' behavior, increases their dedication to work, and raises their teaching levels [111]. The study shows that it is important that principals as pedagogic leaders lead evaluation processes, reflection, feedback and measure of all related to teaching in schools [48]. To lead these processes in a wise manner requires specific professional skills, the use of the appropriate evaluation tools and transformative leadership.

Three main characteristics distinguish between transactional and transformative leadership. The first one is extensive use by the transactional principal of "conditional" rewards - leadership focusing on the exchange of sources by granting tangible (monetary) or 
intangible support to employees for their efforts. The second characteristic is management by exception, i.e. the use of negative feedback, referring to corrective action as required. The focus of this type of management is on setting standards and on monitoring deviations from these standards. The third characteristic is passive management: the leader will only intervene if there are real problems. These characteristics are a mechanical means of control, used when the emphasis is placed first on optimal production output [11], and can correspond in nature to principals' value systems. According to this description, it is reasonable to assume that principals with pragmatic value systems will adopt transactional leadership styles more than principals with moral value systems, who will adopt a transformative leadership style.

\section{Conclusions and Recommendations}

The literary review of leadership, leadership styles, and a leader's value systems with an emphasison school principals is suggested.The review indicates clear signs of the contribution of transformational leadership on the improvement in functioning of school management, particularly on teaching processes as reflected in the students' learning. In addition, transformational leadership empowers teachers and raises their motivation towards their profession.

The effect of value systems on leadership styles of school principals is examined. The work hypothesis is that principals with moral value systems will tend to adopt a transformative leadership style, while principals with pragmatic leadership styles will tend to adopt a transactional leadership style. This hypothesis is based onshedding light on potential theoretical links between school principals' value systems and leadership styles. Therefore, the characteristics of moral/pragmatic value systems and transactional/transformative leadership styles, with an emphasis on the great similarity in substance between these characteristics are considered.

It is showed thatprincipals with moral value systems will perceive a transformational leadership style as a means to empowerment and improvement in teacher performance, will be more interested in the process and not merely in the final result, will perform evaluations, and will accompany the teachers in regular, consistent, reflective feedback. Principals with pragmatic value systems, who adopt transactional leadership styles, will be more likely to consider it a means for rewards and judgment than principals with transformative leadership styles. The characteristics of a pragmatic value system overlap those of a transactional leadership, and therefore the chance is higher that these principals will adopt this leadership style.

The review of research and theoretical discussions realized in this paper revealed a positive correlation between a pragmatic value system and transactional leadership style, and also a positive correlation between a moral value system and transformative leadership style.

There view allows for making a conclusion that it is necessary to carry out a profound research on Arab education system in Israel by means of integrated quantitative and qualitative methods. The research should involve examination of the value systems of school principals, the study of their leadership styles, and the search for potential correlations between the value systems and leadership styles. This research may contribute to the understanding of the difficulties andobstacles faced by school principals in making decisionson a more intelligent introduction and use of effective organizational processes.

\section{References}

[1] Abu-Hussain, J. (1998). Value systems and leadership styles of school principals in Israel's Arab sector. In: Studies in educational Administration and Organization, 22, 87-100 (Hebrew).

[2] Abu-Hussain, J.\& Essawi, M. (2014) Value Orientation and Leadership Style among School Principals in Israel's Arab Education System, International Journal of Business Administration, Sciedu Press,Vol.5, N3, 49-58

[3] Adizes, I. (1991). Mastering change: The power of mutual trust and respect in personal life. Family life, business and society. Santa Monica, California.

[4] Armstrong, M., H. \& Trueblood, C. (1985). The Importance of Principals' Values and their Relationships to the Promotion of Professional teachers Growth. Eric Document Reproduction service (ED263668).

[5] Avolio, B.J., Walumbwa, F.O. \& Weber, T.J. (2009). Leadership: Current Theories, Research, and Future Directions. Annual Review of Psychology, 60, 421-449.

[6] Avni Rasha (2008). Perception of the role of the school principal in Israel. Report of Professional Committee for Consolidation of Recommendations on Ministry of Education Policy. (Hebrew).

[7] Bar-El, Z.; Noimeir, M. (1996). Meetings with psychology. Pub: Reches. (Hebrew).

[8] Bass, B., M. \& Avolio J. B. (1993). Transformational leadership and organizational culture, Public Administration Quarterly, spring, 112-121.

[9] Bass, B. (1999). Two decades of research and development in transformational leadership. European journal of work and Organizational Psychology, 8(1), 9-32.

[10] Bass, B. M. \& Avolio, B. J. (1994). Improving Organizational Effectiveness through Transformational Leadership. Thousand Oaks, CA: Sage Publications.

[11] Bass, B.M. (1985). Leadership and Performance beyond Expectations. New York: Free Press.

[12] Bennett, N. \& Anderson, L. (2003). Rethinking educational leadership. Sage publications Ltd, London.

[13] Birasnav, M., Rangnekar, S. \& Dalpati, A. (2011). Transformational leadership and human capital benefits: the role of knowledge management, Leadership \& Organization Development Journal, 32 (2), 106-126.

[14] Blake, R. R. \& Mouton, J. S. (1964). The management grid, Houston, Gulf publishing.

[15] Bogler, R. (2001). The Influence of Leadership Style on Teacher Job Satisfaction, Educational Administration Quarterly, 37 (5), 662-683.

[16] Bogler, R. (2002). Two profiles of schoolteachers: a discriminate analysis of job satisfaction, Teaching and Teacher Education, 18, 665-673.

[17] Bolden, R., Gosling, J., Marturano, A. \& Dennison, P. (2003). A Review of Leadership Theory and Competency Frameworks. Centre for Leadership Studies, University of Exeter, Cross mead Barley Lane Dunsford Hill Exeter EX4 1TF United Kingdom.

[18] Burns, J.M. (1978). Leadership. New York: Harper Torchbooks.

[19] Catano, A. \& Stronge, J. H. (2007). What do we expect of school principals? Congruence between principal evaluation and performance standards. Leadership in Education. 10 (4). 379-399.

[20] Cerni, T. \& Curtis, G.J. \& Colmar, S.H. (2008). Information processing and leadership styles: Constructive thinking and transformational leadership. Journal of Leadership Studies, 2 (1), 60-73.

[21] Charbonnier-Voirin, A., \& El Akremi A. \& Vandenberghe, C. (2010). A Multilevel Model of Transformational Leadership and Adaptive Performance and the Moderating Role of Climate for Innovation. Group \& Organization Management, 35 (6), 699-726. 
[22] Cheng, Y. Ch. (1997). The Transformational Leadership for School Effectiveness and Development in the New Century. Paper read at International Symposium of Quality Training of Primary and Secondary Principals toward the 21st Century, January 20-24, at Nanjing, China.

[23] Cherry, B. (2007). Running Head: Transformational versus Transaction Leadership. 28 August 2007.

[24] Clark, C. \& Pratt, S. (1985). Leaderships Four part progress, Management today, March 1985.

[25] Cole, G.A. (1995). Organisational Behaviour: Theory and Practice, D.P. Publications.

[26] Collins, J. (2001). Level 5 Leadership-The Triumph of Humility and Fierce Resolve, Harvard Business Review, January, 67-76.

[27] Conly, S. \& Glasman, N. (2008). Fear, the school organization, and teacher evaluation. Educational Policy, 22 (1), 63-85.

[28] Cooper, C.D., Scandura, T.A. \& Schriesheim, C.A. (2005). Looking forward but learning from our past: Potential challenges to developing authentic leadership theory and authentic leaders, The Leadership Quarterly, 16 (3), 475-493.

[29] Crow, G. M. (2006). Complexity and the beginning principal in the United States: perspectives on socialization. Journal of Educational Administration. 44 (4). 310-325.

[30] Daley, G. \& Kim, L. (2010). A teacher evaluation system that works. Institute for Excellence in teaching. Santa Monica: CA.

[31] Danielson, S. (2001). New trends in Teacher Evaluation. Educational Leadership, 58 (5): 12-15.

[32] Darling-Hammond, L., LaPointe, M., Meyerson, D., Orr. M. T. \& Cohen, C. (2007). Preparing School Leaders for a Changing World: Lessons from Exemplary Leadership Development Programs. Stanford, CA: Stanford University, Stanford Educational Leadership Institute.

[33] Davies, B. (2007). Developing Sustainable Leadership. London: Paul Chapman Publishing.

[34] Day, C., Harris, A. \& Hadfield, M. (2001). Challenging the Orthodoxy of Effective School Leadership, International Journal of Leadership in Education 4 (1): 39-56.

[35] Deluga, R. J. (1988). Relationship of Transformational and Transactional Leadership with Employee Influencing Strategies. Group Organization Management December 13 (4), 456-467.

[36] Dinham, S. (2007). How Schools Get Moving and Keep Improving: Leadership for Teacher Learning, Student Success and School Renewal, Australian Journal of Education, 51 (3), 263-275.

[37] England, G. W. (1975). The Manager and His Values, an International Perspective. Cambridge, Mass: Ballinger.

[38] Eppard, R. (2004). Transformational and Transactional Leadership Styles as they predict constructive culture and defensive culture. Doctor of Philosophy in Human Development, United States: Randy G. Eppard.

[39] Eyal, R. \& Roth, G. (2011). Principals’ leadership and teachers' motivation Self-determination theory analysis, Journal of Educational Administration, 49 (3), 256-275.

[40] Ferrer, M. (2009). Relationship of personal characteristics, leadership styles, and job satisfaction to adversity quotient of academic Heads of colleges and universities in the national capital region. A Dissertation Presented to The Faculty of the Graduate School Polytechnic University of the Philippines Sta. Mesa, Manila

[41] Feather. N. T. (1995). Values, valences\& choice: The influence of values on the perceived attractiveness and choice of alternatives. Journal of personality and Social psychology, 68, 1135-1151.

[42] Fielder, F. E. (1972). Leadership. New York, General learning press.

[43] Freeman, G. (2011). Spirituality and Servant Leadership: A Conceptual Model and Research Proposal, Emerging Leadership Journeys, 4 (1), 120-140.

[44] Fullan, M. (2001). Leading in a culture of change. San Francisco: Jossey-Bass.

[45] Gao, F., Bai, S. \& Shi, K. (2011). The Effects of Transformational Leadership in Chinese Family Business How Should Family Business Lead Their Family Employees? International Journal of Trade, Economics and Finance, 2 (3), 218-224.

[46] Gaziel, H. (1982). Relationship between the values of students of educational administration and their perceptions of ideal management style. Iyunin beminhal ubairgun hachinuch (Studies in educational administration and organization), 10, 57-68 (Hebrew).
[47] Gill, A., Fitzgerald, S., Bhutani, S., Mand, H. \& Sharma, S. (2010). The relationship between transformational leadership and employee desire for empowerment, International Journal of Contemporary Hospitality Management, 22 (2), 263-273.

[48] Goldring, E., Porter, A.C., Murphy, J., Elliot, S.N. \& Cravens, X. (2007). Assessing Learning-centered Leadership. Connections to research, professional standards and current practices. Prepared for the Wallace Foundation Grant on Leadership Assessment.

[49] Gupta, K. P. (2009). Cost Management: Measuring, Monitoring \& Motivating Performance, Global India Publications.

[50] Guterman, K. (2010). On the road to educational leadership: The next step, teaching observations and pedagogical discourse as the focus of the educational process and pedagogical growth in the school. In: Hahinuch Vesvivo (Education and Context): The Kibbutzim College of Education, Technology and Arts, 32, 149167. (Hebrew).

[51] Hallinger, P. (2005). Instructional Leadership and the School Principal: A Passing Fancy that Refuses to Fade Away. Leadership and Policy in Schools, 4, 1-20.

[52] Hayajneh, A. F. (1990). Personal value system of American and Jordanian Manager: A cross cultural study. Dissertation Abstract International, University of North Texas-1991, 2450A.

[53] Hay, I. (2006). Leadership of Stability and Leadership of volatility: Transactional and Transformational Leaderships Compared. Academic Leadership, the online Journal, Volume 4 Issue 4, Posted On Tue, Sep 142010 15: 10: 53.

[54] Hebert, E. (2011). The Relationship between Emotional Intelligence, Transformational Leadership, and Effectiveness in School Principals. Educational Policy Studies Dissertations. Georgia State University.

[55] Hersey, P. \& Blanchard, H. (1980). The management change, Training and development journal, 34 (6): pp. 80-98.

[56] Hoerr, T. R. (2008). What is instructional leadership? Educational Leadership, 65 (4), 84-85.

[57] House, R.J. (1971). A Path Goal Theory of Leader Effectiveness, Administrative Science Quarterly, Vol. 16, No. 3, pp. 321-339.

[58] Huber, S. \& Muijs, D. (2010). School Leadership-International Perspectives, School Leadership Effectiveness: The Growing Insight in the Importance of School Leadership for the Quality and Development of Schools and Their Pupils, Chapter 4, 10, 57-77.

[59] Inbar, D. (2000). Managing Diversity: The Educational Challenge. Or Yehuda: Rekhes. (Hebrew).

[60] Inbar, D. (2009). Educational leadership in an era of contradictions. Educational Echo, 83 (4): 52-54. (Hebrew).

[61] Ismail, et. al. (2010). Transformational and Transactional Leadership Styles as a Predictor of Individual Outcomes, Theoretical and Applied Economics, XVII, 6 (547), 89-104.

[62] Judge, T. \& Piccolo, R. (2004).Transformational and Transactional Leadership: A Meta-Analytic Test of Their Relative Validity, Journal of Applied Psychology, 5, 755-768.

[63] Knafo, A., Schwartz, S. (2003). Passing on Family Values. Jerusalem: NCJW Research Institute for Innovation in Education (Hebrew).

[64] Koh, W., Steers, R. \& Terborg, J. (1995). The effects of transformational leadership on teacher attitudes and student performance in Singapore. Journal of Organizational Behavior, 16 (4), 319-333.

[65] Kotter, J. P. (1996). Leading Change. Harvard Business School Press.

[66] Koys, D. J. (2001). The effects of employee satisfaction, Organizational citizenship behavior and turnover on organizational effectiveness: A unit-level, longitudinal Study. Personnel psychology, 54: pp. 101-114.

[67] Leithwood, K. (1992). The Move toward Transformational Leadership. Educational Leadership, 49 (5), 8-12.

[68] Leithwood, K. (1997). Distributed Leadership in Secondary Schools. Paper read at Annual Meeting of the American Educational Research Association, March 24-28, at Chicago, IL.

[69] Leithwood, K., Day, C., Sammons, P., Harris, A. \& Hopkins, D. (2006). Successful School Leadership: What it is and how it influences pupil learning. London: DfES.

[70] Leithwood, K., Day, C., Sammons, P., Harris, A. \& Hopkins, D. (2007). Seven strong claims about successful school leadership, Birmingham: NCSL.

[71] Leithwood, K., Louis, K. S., Anderson, S. \& Wahlstrom, K. (2004). How leadership influences student learning (paper commissioned by the Wallace Foundation). Minneapolis: University of Minnesota. 
[72] Leithwood, K.A. \& Riehl, C. (2003). What we know about successful school leadership. Philadelphia, PA: Laboratory for Student Success, Temple University.

[73] Levy, A. (2008). Management and leadership change and innovation. Pub: Rimonim. (Hebrew).

[74] Lewin, K. ; Lippit, R. \& White's, R. (1939). Patterns of aggressive behavior in experimentally created social climates. Journal of social psychology, 10, pp. 271-301.

[75] Lewis, P. \& Murphy, R. (2008). Effective School leadership. National College for School Leadership.

[76] Ling, W., Reagatte, R.R., Navon, G. \& Jerschow, A. (2008). Assessment of glycosaminoglycan concentration in vivo by chemical exchange-dependent saturation transfer (gagCEST). Proc Natel a cad Sci USA. 105, pp 2266-70.

[77] Lowe, K., Kroeck, G. \& Sivasubramaniam, N. (1996). Effectiveness correlates of transformational and transactional leadership: A meta-analytic review of the $M L Q$ literature, Leadership Quarterly, 7 (3), 385-425.

[78] McClelland, D.C. (1997). Human Motivations. Cambridge university press.

[79] Mandell, B. \& Pherwani, S. (2003). Relationship between Emotional Intelligence and Transformational Leadership Style: A Gender Comparison, Journal of Business and Psychology, 17(3), 387-404.

[80] Marshall, K. (2005). It's time to rethink teacher supervision and evaluation, Phi Delta Kappa, 86 (10), 727-736.

[81] Marzano, R. J., Waters, T. \& McNulty, B. A. (2005). School leadership that works: From research to results. Alexandria, VA: Association for Supervision and Curriculum Development.

[82] Maxwell, J.C. (2001). The 17 Indisputable Laws of Teamwork: Embrace Them and Empower Your Team. Thomas Nelson Publishers, 256pp.

[83] McGhee, M.W. \& Nelson, S.W. (2005). Sacrificing Leaders, Villainizing Leadership: How Educational Accountability Policies Impair School Leadership. Phi Delta Kappan, 86(5), 367-372.

[84] Moorhead, R. \& W. Nediger, (1991). The Impact of Values on a Principal's Daily Activities. Journal of Educational Administration, Vol.29 No. 2, pp. 5-24.

[85] Mulford, B. (2003). School leaders: changing roles and Impact on Teacher and school effectiveness. A paper commissioned by the Education and Training Policy Division, OECD, for the Activity Attracting, Developing and Retaining Effective Teachers.

[86] Murphy, J., Elliott, S.N., Goldring, E. \& Porter, A.C. (2006) Learning-Centered Leadership: A Conceptual Foundation. Learning Sciences Institute, Vanderbilt University.

[87] Northouse, P. G. (1997). Leadership theory and practice. Thousand Oaks: Sage Publication.

[88] Oplatka, I. (2007) Foundations of educational managementLeadership and management in educational organizations. Haifa: Pardess.(Hebrew).

[89] Oplatka, I. (2001). Types of Difficulties in the Induction Stage: Retrospectives Voices of Women Principals. . Planning and Changing. 32 (1 \& 2). 46-57.

[90] Oplatka, I. (2004). The Arrival of a New Woman Principal and Teachers' Self-Renewal: Reflections from Life Stories of MidCareer Teachers. Planning and Changing. 35 (1 \& 2). 55-68.

[91] Pagan, N. \& Edlund, C. (2008). Transformational Leadership Review of "The Leadership Challenge-A Call for the Transformational Leader”, Managing Organizational Behavior, spring 2008, 1-5.

[92] Peterson, K. (2004). Research on School Teacher Evaluation, NASSP Bulletin, 88(639) 60-79.

[93] Popper, M. \& Liphshits,, R.(1992). Choaching on leadership. Leadership and organizational development journal, Vol. 13, No. 7, pp 15-19.

[94] Popper, M. (1994). On Managers as Leaders. University of Tel Aviv: Ramot. (Hebrew).

[95] Popper, M. (2009). Out of sight, larger than life. Educational Echo, 4 (pg), 44-48.(Hebrew).

[96] Popper, M. \& Aviahu, R. (1992). On Leadership. Tel-Aviv: Ministry of Defense. (Hebrew)

[97] Reddin, W. J. (1970). Managerial Effectiveness. New York: McGraw-Hill.

[98] Robbins, S. P. (2001). Organizational behavior. Prentice Hall, 9th edition.

[99] Rokeach, M. (1973). The Nature of Human Values. New York: Free Press.
[100] Rowold, J. \& Schlotz, W. (2009). Transformational and Transactional Leadership and Followers, Chronic Stress, Leadership Review, 9, 35-48.

[101] Sagiv, L. \& Schwartz, S. H. (1995). Value priorities \& Readiness for out group social contact. Journal of personality and Social psychology, 69, 437-448.

[102] Sagnak, M. (2010). The Relationship between Transformational School Leadership and Ethical Climate, Educational Sciences: Theory \& Practice, 10 (2), 1135-1152.

[103] Sahın, S. (2004). The Relationship between Transformational and Transactional Leadership Styles of School Principals and School Culture (The case of Izmir, Turkey). Kuram ve Uygulamada Eğitim Bilimleri, 4 (2), 387-395.

[104] Schwartz, S. H. (1996). Value priorities \& Behavior: Applying a theory of integrated value systems. In C. Seligman, J. M. Olson\& M. P. Zanna (Eds.), The Ontario symposium: Vol. 8. The psychology of values (pp. 1-24). Hillsdale, NJ: Lawrence Erlbaum.

[105] Schwartz, S. H. \& Bardi, A. (2001). Value hierarchies across cultures: Taking a similarities perspective. Journal of cross cultural psychology, 32, 268-290.

[106] Sergiovanni, T. J. (1984). Leadership and Excellence in Schooling. Educational Leadership, 41 (5), 4-13.

[107] Sergiovanni, T. J. (1990). Adding value to leadership gets extraordinary results, Educational leadership, 47, pp. 23-27.

[108] Sergiovanni, T. J. (2002). Theoretical and practical aspects of school administration. Tel Aviv: Open University. (Hebrew).

[109] Sikula A. F. (1971). Values and Value Systems: Importance and Relationship to Managerial and Organizational Behavior, Journal of Psychology, 25, pp. 227-286.

[110] Sorenson, D. \& Machell, J. (1996). Quality Schools through Quality Leadership. Paper presented at the Annual National Conference on Creating the Quality School (5th, Oklahoma City, OK, March 27-30, 1996).

[111] Southworth, G. (2004). Primary School Leadership in Context: Leading small, medium and large sized schools. London: Routledge Falmer.

[112] Southworth, G. (2009). Passionate work: towards a natural history of headship. In Davies \& Brighouse (Eds) the Essentials of School Leadership, London, Sage, $2^{\text {nd }} E d$.

[113] Stiggins, R. \& Duke, D. (2008). Effective instructional leadership requires assessment leadership, Phi Delta Kappa, 90, 285-291.

[114] Stogdill, R. M. (1948). Personal factors associated with leadership: A survey of the literature. Journal of Psychology, 25, 35-71.

[115] Stogdill R. M. (1969). Validity of leader behavior description. Personnel Psychology, Vol. 22, pp. 153-158.

[116] Su-Tan, L. (2011). Transformational Leadership: Leadership in Education. Educause.edu. According to the abstract, Created by Su-Tuan Lulee (WIDE) on March 13, 2011.

[117] Thompson, M.D. (2000). Gender, Leadership Orientation, and Effectiveness: Testing the Theoretical Models of Bolman \& Deal and Quinn. Sex Roles, 42, Nos. 11/12, 969-992.

[118] Wang, G. \& Oh, I.S., Courtright, S. (2011). Transformational Leadership and Performance across Criteria and Levels: A MetaAnalytic Review of 25 Years of Research. Group Organization Management, 36 (2), 223-270

[119] Warrick, D.D. (1981). Leadership Styles and Their Consequences, Journal of Experiential Learning and Simulation, 3-4, 155-172.

[120] Waters, T., Marzano, R. J. \& McNulty, B. (2003). Balanced leadership: What 30 years of research tells us about the effect of leadership on student achievement. Aurora, CO: Mid-continent Research for Education and Learning. Available online at www.mcrel.org.

[121] Wergin, I. (2006). The role of the principal in the educational system. Presented to Committee for Education, Culture and Sports. Jerusalem: Haknesset, Center for Research and Information. (Hebrew).

[122] Wren, D. (2005). The History of Management Thought. Fifth Edition, Susan Elbe, United States of America.

[123] Yukl, G. A. (1994). Leadership in Organizations. $3^{\text {rd }}$ Ed. Englewood Cliffs, NJ: Prentice-Hall.

[124] Zimmerman, S. \& Deckert-Pelton, M. (2003). Evaluating the evaluators: Teachers' perceptions of the principal's role in professional evaluation. National Association of Secondary School Principals. NASSP Bulletin, 87, 636; 28-37. 